\title{
Difference in Computer Vision Syndrome between Laptop and Desktop Computer Users
}

\author{
Putri Anggrainy'), Taufik Ashar'2), Rodiah Rahmawaty Lubis3) \\ 1)Department of Occupational Health and Safety, Faculty Public Health, \\ Universitas Sumatera Utara \\ 2) Department of Environmental Health, Faculty Public Health, \\ Universitas Sumatera Utara \\ 3) Department of Ophthalmology, Faculty of Medicine, Universitas North Sumatera
}

\begin{abstract}
Background: Occupational health is a key component of an industry. This is because a strong safety culture boosts productivity, employee morale, and employee retention. A strong ergonomics integration prevents injuries and increases productivity. They make the workplace safer and reduce costs. Ergonomics also must be incorporated and seen as a value. It needs to be built into a corporate culture and be integrated into everything any company does on a daily basis, including that in the administrative office where workers frequently use computers. This study aimed to analyze difference in computer-attributed vision problem between laptop and desktop computer users.

Subjects and Method: This was a cross sectional study conducted in North Sumatera. A sample of 60 subjects consisting of 30 laptop users and 30 desktop users were selected for this study by purposive sampling. The dependent variable was vision problem. The independent variable was computer type. The data were collected by questionnaire and tested by Mann Whitney test.

Results: Among the laptop users, 80\% experienced neck pain, $77 \%$ eye strain, and $70 \%$ low back pain. Among the desktop-computer user, 50\% experienced neck pain, 77\% eye fatigue, and 33\% eye irritation. Mean score of complaints in the laptop user group was 2.54 units higher than the desktop-computer user group $(\mathrm{p}=0.001)$.

Conclusion: Laptop users experienced more complaints than desktop-computer users. Workers using computers are suggested to have regular break to allow body organs to take a rest. Workers are also suggested to work at an ample distance between eyes and computer screen. Employers are responsible for providing a safe and healthful workplace for their workers.
\end{abstract}

Keywords: vision problem, computer-attributed, laptop, desktop computer, agronomy

\section{Correspondence:}

Putri Anggrainy. Department of Occupational Health and Safety, Faculty Public Health, Universitas North Sumatera. Email: putri.anggrainy@gmail.com. Mobile: +6285763191981.

\section{BACKGROUND}

The use of computers and laptops at this time is very broad, almost all human activities use this technology to complete their work. Aside from being a data processing tool, the device also functions as a communication tool and an information provider.

Computers and laptops are almost used by all employees, both for administrative staff and field workers. With a computer, the work becomes more practical and efficient. In addition, it cannot be denied that working with computer or laptop has the potential to cause occupational diseases. Occupational diseases caused by the use of computers must be considered carefully so that their utilization can really increase the productivity of the work (Anies, 2014).

The use of computers that are too long and continuous can cause illness in- 
cluding occupational health hazard, commonly referred to as computer vision syndrome and this syndrome is the number one occupational hazard in the 21st century (Torrey, 2003). The US National Institute for Occupational Safety and Health states that around $90 \%$ of people who spend three hours or more a day on a computer can cause Computer Vision Syndrome (CVS) (Beck, 2010). CVS is a condition where the eyes focus on paying attention to computers or other display devices for a long time continuously. The most common symptoms are eye fatigue, headache, blurred vision, dry eyes and neck or shoulder pain (AOA, 2016). People who work more than 2 to 3 hours a day with computers is at risk of experiencing CVS (Rathore, 2017).

The main contributing factors associated with CVS are environments such as improper lighting, monitor position and visibility. Another factor is the user's visual abilities such as uncorrected refraction errors, oculomotor disorders and the presence of abnormalities in the eyes (Gowrinsankaran and Sheedy, 2014). Mowry \& Ison (2015) said that CVS risk factors consist of physiological and environmental factors. Physiological factors such as frequency of blinking, age, sex, systemic disease, treatment, use of contact lenses and cosmetics, and environmental factors include display display, length of exposure, lighting, contrast, glare, temperature, humidity, noise, ergonomics, furniture, radiation, including the workload given.

Gawrinsankaran and Sheedy (2014) classified CVS symptoms into four symptoms including internal ocular symptoms (tense eyes, eye and around eyes, tired eyes, and headaches), external ocular symptoms (dry eyes, irritation, red eyes, and burning sensation) visual symptoms (blurred eyes and double vision), and musculoskeletal symptoms (neck, shoulder pain, wrists, and fingers).

The use of laptops and desktop computers at work can cause CVS to its users. Felix, et al. (2013) states that the magnetic field of the LCD for desktop computers is lower than that of a laptop. Renesinghe, et al. (2016) found that on average, office workers who use computers for 6-9 hours per day, often experience headaches (45.7\%), followed by dry eyes (31.1\%), and pain around the eyes ( 28.7\%). While Akinbinu and Mashalla (2014) found that working too long in front of a computer can cause headaches (30.9\%), tense eyes (30.9\%), double vision (12.9\%), watery eyes (10.8\%), glaze (10.1\%), and redness (4.3\%). Reddy, et al. (2013) said that working for 2 hours or more continuously with a computer is more likely to experience CVS, a symptom that often arises is a headache followed by tense eyes. Based on previous study, researchers were interested in conducting comparative study on both devices.

\section{SUBJECTS AND METHOD \\ 1. Study Design \\ This was a comparative analytic with cross sectional study design.}

\section{Population and Sample}

The study population was Medan Class I Port Health Office employees. The number of samples was 60 people, consisting of 30 laptop users and 30 desktop computer users. The sampling technique in this study was non-probability sampling technique using purposive sampling.

\section{Study Variables}

The dependent variable in this study was the incidence of Computer Vision Syndrome (CVS) and the independent variable was the computer type.

\section{Data Analysis}

The data were obtained from interviews using questionnaire tools. The CVS symptoms that were asked to the respondents 
consisted of 13 symptoms: tense eyes, eye and around eyes, tired eyes, headaches, dry eyes, irritation, red eyes, blurred vision, double vision, neck pain, and shoulder pain and pain in wrist / fingers.

The data analysis test was conducted using SPSS software. The presentation of descriptive data for categorical types was presented in the form of percentages and frequency distributions, while numerical data would be seen as mean, standard deviation and minimum and maximum values. Bivariate analysis was conducted using Mann Whitney test.

Table 1. Frequency Distribution of Study Subjects based on the Incidence of CVS

\begin{tabular}{|c|c|c|c|c|}
\hline \multirow{2}{*}{ Symptoms of CVS } & \multicolumn{2}{|c|}{ Laptop } & \multicolumn{2}{|c|}{ Computer-Desktop } \\
\hline & $\mathbf{n}$ & $\%$ & $\mathbf{n}$ & $\%$ \\
\hline \multicolumn{5}{|l|}{ Ocular Symptoms } \\
\hline \multicolumn{5}{|l|}{ Internal Ocular Symptoms } \\
\hline The Tense in the Eyes & 23 & $77 \%$ & 8 & $27 \%$ \\
\hline $\begin{array}{l}\text { Pain in the eyes and around the } \\
\text { eyes }\end{array}$ & 13 & $43 \%$ & 6 & $20 \%$ \\
\hline Eyestrain & 20 & $67 \%$ & 23 & $77 \%$ \\
\hline Headaches & 14 & $47 \%$ & 5 & $17 \%$ \\
\hline \multicolumn{5}{|l|}{ External Ocular Symptoms } \\
\hline Burning sensation in the eyes & 2 & $7 \%$ & 1 & $3 \%$ \\
\hline Eye irritation & 15 & $50 \%$ & 10 & $33 \%$ \\
\hline Dry eyes & 19 & $63 \%$ & 7 & $23 \%$ \\
\hline Red eyes & 6 & $20 \%$ & 7 & $23 \%$ \\
\hline \multicolumn{5}{|l|}{ Visual Symptoms } \\
\hline Multiple Vision & 4 & $13 \%$ & 2 & $7 \%$ \\
\hline Blurred vision & 17 & $57 \%$ & 10 & $33 \%$ \\
\hline \multicolumn{5}{|l|}{ Musculoskeletal Symptoms } \\
\hline Pain in the neck & 24 & $80 \%$ & 15 & $50 \%$ \\
\hline Pain in the back & 20 & $70 \%$ & 8 & $27 \%$ \\
\hline Pain in the hands and fingers & 5 & $17 \%$ & 4 & $13 \%$ \\
\hline
\end{tabular}

\section{The Score of CVS Incident}

The score of CVS incident showed in Table 2. Table 2 showed that the respondents who work by using laptops experienced more CVS symptoms than workers who use desktop computers.

The average of CVS symptom score experienced by laptop users was 6.07 symptoms with a minimum score of 1 symptom

$\frac{\text { RESULTS }}{\text { 1. The frequency of CVS }}$

The most common symptoms in laptop users are 24 neck pain (80\%), 23 people (77\%), tension in the back of 20 people (70\%), tired eyes 20 people (67\%), and 19 dry eyes (63\%). CVS complaints that most often occur on desktop computer users include: tired eyes as many as 23 people (77\%), neck pain 15 people (50\%), irritable eyes 10 people (33\%), blurred vision 10 people (33\%), the eyes felt tense and back pain was 8 people (27\%). 
Indonesian Journal of Medicine (2018), 3(2): 65-70

https://doi.org/10.26911/theijmed.2018.03.02.01

Table 2. The Results of Mann Whitney Test Analysis of CVS Complaints Score on Laptop and Desktop Computers Users

\begin{tabular}{lccc}
\hline \multicolumn{1}{c}{ CVS Score } & $\begin{array}{c}\text { Laptop Users } \\
\mathbf{n = 3 0}\end{array}$ & $\begin{array}{c}\text { Desktop Computers Users } \\
\mathbf{n = 3 0}\end{array}$ & $\mathbf{p}$ \\
\hline Mean & 6.07 & 3.53 & \\
SD & 2.43 & 1.63 & 0.001 \\
$95 \%$ CI & $5.16-6.98$ & $2.92-4.14$ & \\
Minimal & 1 & 1 & \\
Maximal & 11 & 6 & \\
\hline
\end{tabular}

Based on the analysis of MannWhitney test, it can be concluded that there were significant differences in CVS incidence scores between workers who used laptops and workers who used desktop computers $(\mathrm{p}=0.001)$.

\section{DISCUSSIONS}

CVS or computer vision syndrome was a set of symptoms or disorders of eyes and vision health because the eyes have to focus for a long time in front of a computer (laptop or PC) or other digital devices such as tablets and cellphones. Rosenfield (2011) stated that CVS can affect work productivity for about $64 \%$ to $90 \%$. This syndrome occurred due to too long computer usage. Computer vision syndrome also known as digital eye strain, which was a combination of eye and vision problems associated with computer use (including desktops, laptops, and tablets) and other electronic displays (smartphones and electronic reading devices) (Rosenfield, 2011; Rosenfield, 2016).

Internal ocular symptoms such as tension, pain in the eyes and around the eyes, and tired eyes were most likely related to refractive errors such as accommodation, increased convergence (close reading), and other ocular muscle tension involvement. Accommodation disorders have a significant contribution to CVS symptoms experienced by computer users (Gowrisankaran and Sheedy, 2014).

In this study, it was found that laptop users were more likely to experience musculoskeletal symptoms. Neck pain and back pain were the most common complaints. Unlike desktops, laptops were more portable, lighter and can be easily moved, so the workers pay less attention to their body postures when they were working. A very low monitor position from the horizontal view of the eye caused the workers to bend more often when working. A non-ergonomic position in working was one of the factors that cause neck and back pain complaints.

Monitors on the laptops were generally smaller than desktops. Display on a laptop screen was smaller than computerdesktops. In order to get a clear vision, laptop users would usually get closer to the monitor. Too close visibility to the monitor improved the eye accommodation system. The increased need for ocular convergence when reading through the computer was associated to higher internal ocular symptoms (Gawrisankaran and Sheedy, 2014). Close distance lead to excess accommodation which results in hard work of the ciliary muscles of the eye which were manifested as tension and headaches (Akinbinu and Mashalla, 2014).

Contrast monitors that were too bright on computer-desktops along with poor lighting could lead to glare on the computer screen. Reflection from the computer screen also caused the symptoms of visual discomfort. In addition to the effects on visual performance, glare also 
caused significant internal strain symptoms, pain around the eyes, tired eyes, and headaches (Gawrisankaran and Sheedy, 2014). The retina was the deepest layer of the eye, it was also the part of the eye that was sensitive to light, and it contained cone cells and stem cells (Guyton and Hall, 2016). Eyes that focus too long on the computer monitor screen would cause fatigue in the retina that was manifested by symptoms of tired eyes.

A higher screen position resulted in an upward viewpoint which cause greater discomfort in the neck and open eyes. Larger open eyelids could lead to increased evaporation of tears, which might be associated with dry eyes and irritation (Gawrisankaran and Sheedy, 2014).

It was recommended to use 20-20-20 tricks while working with both laptops and desktop computers. In every 20 minutes of work, people need to take a rest for 20 seconds by focusing on an object of 20 feet far (6 meters) or close their eyes (AOA, 2016; Galinsky and Ginsberg, 2016). People should install the eye care applications on laptops and desktop computers to remind them to always apply 20-20-20 tricks when working

Designing the workplace and ergonomic position when working. When using a computer, the monitor should be positioned at a distance of $40-60 \mathrm{~cm}$ from the eye, or adjusted to each individual's needs. The monitor position was arranged in a good way, slightly tilted backwards for $10^{\circ}$ $20^{\circ}$ from an upright position, the top of the monitor was parallel or slightly lower than the horizontal height of the eye and sit in an upright position. Sitting with a soft seat with arm support for typing and foot rest to keep the feet flat on the floor, moving document holders, computers with removable keyboards, and screens to maintain the posture were recommended (OSHA,
1997; Affandi, 2005; Loh and Reddy, 2008; Rathore, 2017).

The lighting has to be adequate. The lighting in the room must be between 300500 lux (Stack et al., 2016), while according to Kroemer (2001) was between 200-500 lux. The lighting might be a little dim, but this was very helpful to keep the lumination that matched on the monitor screen (Kroemer, 2001).

Computer workers were encouraged to blink more frequently (12-18 times a minute). Regular eye movements along with flashing could help in spreading the tears throughout the eyes to keep them hydrated. Prolonged view to the computer screen reduced the range of motion of the eyeball so that the eyes were dehydrated and this can lead to CVS (Affandi, 2005; Gupta et al., 2014; Bali et al., 2014, Gawrisankaran and Sheedy, 2014; Rathore, 2017).

Special glasses might be needed by computer workers over the age of 40 years old, using contact lenses, and using bifocal glasses (Gawrisankaran and Sheedy, 2014; Bali et al., 2014). People can also apply eye fluids to reduce dry eye complaints (Loh and Reddy, 2008; Reddy et al., 2013; Gupta et al., 2014).

Always consume foods which contained rich omega-3 fatty acids, zinc, vitamin $\mathrm{C}$, vitamin $\mathrm{A}$ and vitamin E. Eat nutritious foods (green leafy vegetables) such as spinach, eggs, nuts, beans, carrots, fruit (oranges, lemons), tomatoes, salmon, and others (Rathore, 2017).

\begin{tabular}{l}
\hline REFERENCES \\
\hline Affandi ES (2005). Sindrom Penglihatan \\
Komputer. Majalah Kedokteran Indo- \\
nesia. 55(3). \\
Akinbinu TR, Mashalla RJ (2014). Impact \\
of Computer Technology on Health: \\
Computer Vision Syndrome (CVS).
\end{tabular}


Academic Journal Medical Practice and Review. 5(3): 20-30.

Anies (2014). Kedokteran Okupasi Berbagai Penyakit Akibat Kerja dan Upaya Penanggulangan dari Aspek Kedokteran. Yogyakarta: Ar-Ruzz Media.

AOA (2016). Most Americans Experience Digital Eye Strain from Overexposure to Computers According to Survey. https://www.aoa.org/newsroom/mos $\mathrm{t}$-americans-experience-digital-eyestrain-from-overexposure-to-computers-according-to-survey. Accessed on 31 October 2017.

Beck, Melinda (2010). Becoming a Squinter Nation: Glasses Can Correct Near and Far, but What About Those Screens in Between? The Wall Street Journal. Health Journal. https://www.wsj.com/articles/SB10001424052748704 868604575433361436276340 . Accessed on 20 December 2017.

Felix N, Chizurumoke M, Emmanuel E (2013). Measurement of magnetic fields from liquid crystal display (LCD) computer monitors. International Journal of Current Research, 5(7), 1771-73.

Galinsky E, M.S., \& Ginsberg, S. (2016). Follow the '20-20-20' rule for computer work. Work \& Family Life; New York 31, 7/8 (Jul/Aug 2016): 3.

Gowrisankaran, and Sheedy, James E. (2014). Computer Vision Syndrome: A Review. IOS Press Content Library, 52: 303-314.

Gupta R, Gour D, Meena M (2014). Interventional Cohort Study for Evaluation of Computer Vision Syndrome among Computer Workers. International Journal of Medical Research and Review, 2(1).

Kroemer KH, Kroemer AD (2001). Office Ergonomics. New York: Taylor and Francis Inc.
Loh KY, Reddy SC (2008). Understanding and Preventing Computer Vision Syndrome. Malaysian Family Physician. 3(3).

Mowry C, Ison DC (2015). Assessing Computer Vision Syndrome Risk for Pilots. Journal of Aviation/ Aerospace Education \& Research, 24(2): 79.

OSHA (1997). Working Safely with Video Display Terminal. https://www.osha.gov/Publications/videoDisplay/video Display.html. Accessed on 4 February 2018

Rathore I (2017). Computer Vision Syndrome - An Emerging Occupational Hazard. Research Journal of Science and Technology. 9(02).

Reddy SC, Low CK, Lim YP, Low LL, Mardina F, Nursaleha MP (2013). Computer Vision Syndrome: A Study of Knowledge and Practices in University Students. Journal of Nepal Ophthalmology, 5(10): 161-168.

Rosenfield M (2011). Computer Vision Syndrome: a review of ocular causes and potential treatments. Ophthalmic and Physiological Optics, 31(5): 502-515.

Rosenfield M (2016). Computer vision syndrome (a.k.a digital eye strain). Optometry, 17(1): 1-10.

Stack T, Ostrom LT, Wilhelmsen C (2016). Occupational Ergonomics: a Practical Approach. New Jersey: John Wiley \& Sons.

Sugiyono (2014). Metode Penelitian Kombinasi (Mixed Methods). Bandung: Alfabeta

Torrey J (2003). Understanding Computer Vision Syndrome. Employment Relations Today, 30(1): 45-51 